\title{
Anomalous glacier responses to 20 th century climatic changes in Darwin Cordillera, southern Chile
}

\author{
Per Holmlund \\ Department of Physical Geography, Universily of Stockholm, S-10691 Stockholm, Sweden \\ Humberto Fuenzalida \\ Departamento de Geofisica, Universidad de Chile, Casilla 2777, Santiago, Chile
}

\begin{abstract}
There is an asymmetric pattern response of glaciers in Darwin Cordillera $\left(54-55^{\circ} \mathrm{S}, 69-71^{\circ} \mathrm{W}\right)$ to the climate of the 20 th century. This asymmetry is suggested here as a cause of an increased wind activity which has a pronounced orographic effect. Although climatic records for the last 50 years show a warming trend, as well as no trend in precipitation in the area, some glaciers are advancing. The area is characterized by strong climatic gradients, with high rates of precipitation on the southwestern side of the range and dry conditions on the northern side. Glaciers on the northern and eastern sides show a general trend of receding fronts. With a few exceptions, these glaciers have gradually and uninterruptedly been shrinking since the turn of the century. On the southern rim, the present extents of some glaciers are similar to their 20th century maximum extents. These are, in turn, similar or close to the Holocene maximum. The most extreme sites are the glaciers on either side of Mount Darwin, which is $2469 \mathrm{~m}$ high. The north-facing glacier Ventisquero Marinelli has retreated several hundred metres per year over the last two decades, while the south-facing glaciers in the Pahia Pia basin have advanced during the same period.

In this study, the frontal changes over the last 50 years of 20 glaciers have been analysed. Aerial photographs (verticals) from 1943 and 1984 have been used, as well as oblique aerial photographs from 1993. The general result is that glaciers with accumulation areas facing south and west show somewhat stable fronts, while glaciers facing east and north show receding fronts.
\end{abstract}

\section{INTRODUCTION}

In order to detect and to model a future global warming, we need to analyse paleodata in addition to present data in order to be able to separate natural changes from anthropogenic changes. In the Northern Hemisphere, there is a dense net of climate stations but in the Southern Hemisphere there are far fewer observation points. The need for climatic data from the Southern Hemisphere has been stressed by many authors (Bradley and Jones, 1993). Glaciers and glacier environments are well suited for paleoclimatic studies, as glaciers respond sensitively to changes in climate.

The glaciers in southern Patagonia have not been very well studied. Lliboutry has made an inventory of glaciers in Chile based on aerial photographs taken in the 1940s (Lliboutry, 1956) and recently Aniya (1992) and Warren and Sugden (1993) have made glacier-inventory compilations of the large northern and southern Patagonian ice fields (Fig. 1).

Data on changes in the position of glacier fronts provide information on climatic changes, integrated over a certain period. The response time for valley glaciers is normally decades to centuries. The reaction of a single glacier front is therefore inaccurate, as proxy data is on an annual up to decadal time-scale. But a consistent pattern of the reactions of many glaciers is a good indication of a climate change.

Chile is particularly suited to climate studies with its length of $4000 \mathrm{~km}$ between the southern latitudes of $17^{\circ}$ and $56^{\circ}$ (excluding the Chilean claim to the Antarctic Peninsula). The large ice fields in the south are all situated within the belt dominated by the Westerlies, though the northern Patagonian ice fields are sometimes approached by the southwestern Pacific subtropical anticyclone. These events may block the Westerlies from approaching the Andes at mid-latitudes, causing warm sunny weather at the Patagonian ice fields and stormy weather in the southernmost area.

The topography and the climate of southern Patagonia and Tierra del Fuego show great similarities with the topography and climate of the Scandinavian mountain ranges. These similarities have been studied by Ljungner (1949) in order to find an analogue to Scandinavia, while studying the initiation of the Ice Ages (Ljungner, 1949).

In this paper, we use climatic data and data on changes in glacier extent to analyse the climatic development during the last 50 years. The climate of Chile is influenced by the slopes of the Andes, which produce steep climatic gradients and great variability 


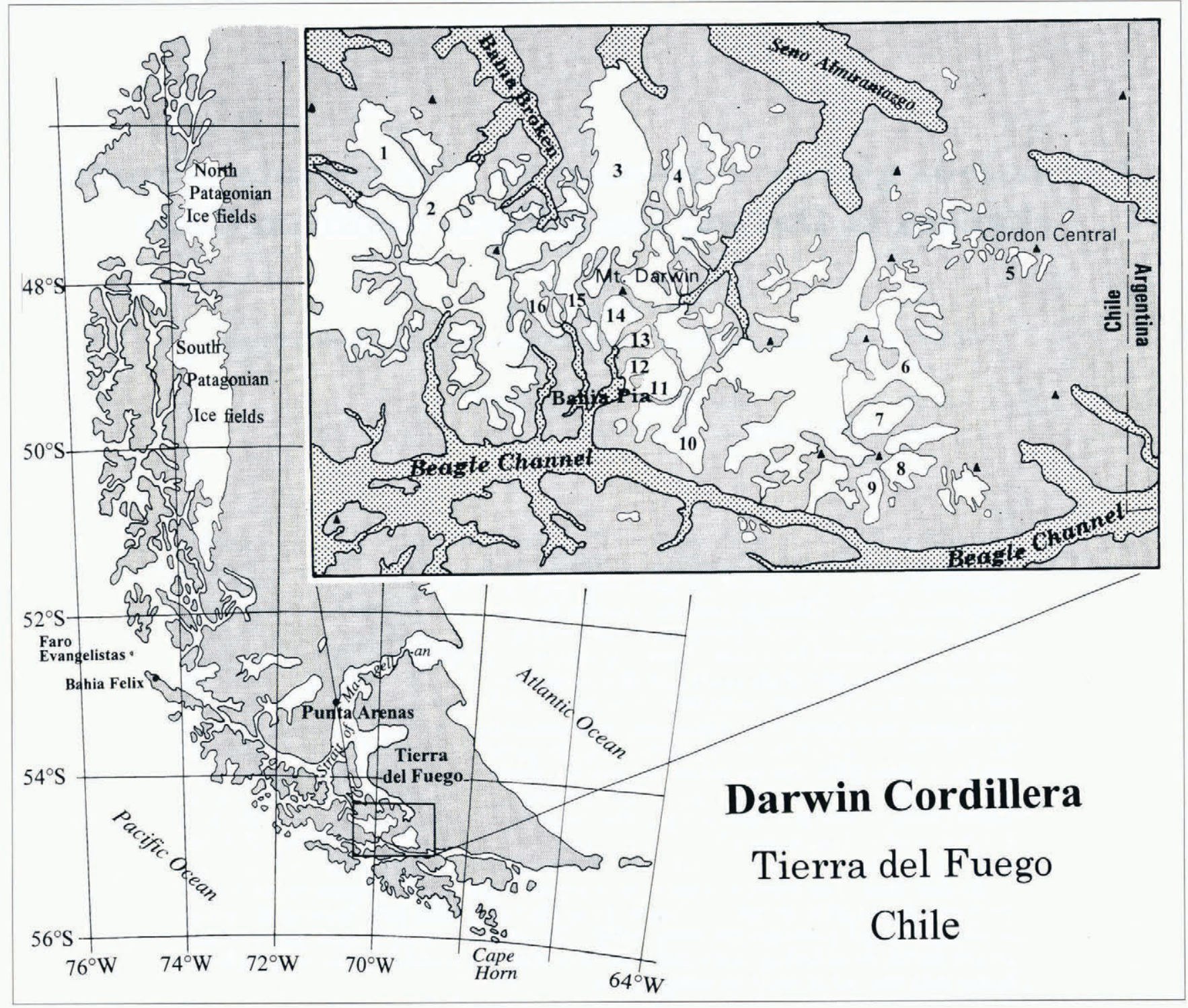

Fig. 1. Location map showing the Patagonian ice fields, as well as a map of Darwin Cordillera. The numbers on the map refer to the text and to Table 1.

between different climatic stations. Over short distances, one may move from a continental to a maritime climate. Glaciers located in such different environments are sensitive to different climatic parameters, a consideration which is also in agreement with observations from Scandinavia (Holmlund, 1993).

On a short-term time-scale, the reaction of calving glaciers to climatic signals is non-linear (Warren, 1993). However, when both calving and non-calving glaciers react in a similar way and there is a geographical pattern in these responses, there is no reason to exclude the calving glaciers from consideration.

We have focused our study on Darwin Cordillera of Tierra del Fuego. The glaciers in the Cordillera were briefly described by Lliboutry (1956). He noted that, prior to 1956, there were no obvious changes in glacier extents during the 20th century. Aerial photographs are available from 1943-44, 1960 and 1984-85. We visited the area in 1993 and 1994. The field study in 1994 included coring trees in order to determine the minimum age of ice uncoverage at sites close to the present glacier fronts. In this paper, changes in the extent of the glaciers since 1943 are interpreted from a climatic point of view using adjacent climatic stations.

Despite the reason, there is a clear geographical asymmetry in the responses of glaciers in Darwin Cordillera. In this part of South America, the climatic stations are sparsely distributed and additional climatic information from, for example, glaciers is needed to describe the 20th century climate. In this paper, we describe what has happened during this century as well as suggest an explanation why it happened.

\section{PHYSICAL SETTINGS}

Darwin Cordillera $\left(54^{\circ} 20^{\prime}-50^{\prime} \mathrm{S}, 68^{\circ} 45^{\prime}-71^{\circ} 20^{\prime} \mathrm{W}\right)$ is the southwestern part of Tierra del Fuego. The mountain range is almost $50 \%$ glacierized. The highest summit reaches $2469 \mathrm{~m}$ a.s.l. and there are about ten summits exceeding $2000 \mathrm{~m}$ in altitude in a distance of $120 \mathrm{~km}$. The southern rim, facing the Beagle Channel, is characterized by deep fjords in a north-south orientation, with glaciers calving into the fjords. The northern side is characterized 
by broader bays and a dryer climate. On the northern side of Seno Almirantaxgo there are rock glaciers, indicating dry environments.

The area is characterized by exposed bedrock outcrops of metasediments and metavolcanics and some deformed and undeformed granitic rocks (Dalziel and Cortés, 1972). The soil cover is sparse and often limited to morainic features and sedimentary deposition. The vegetation is dominated by forests of Nothofagus betuloides with minor stands of Nothofagus antarcticus and Drymis winteri (Canelo).

The winter season in this area extends from June to October (U.S. Navy, 1965) and snowfall comes predominantly with winds from the third quadrant (south to west) (U.S. Navy, 1965). During the winter, the strongest winds come from the west but the coldest air masses come from the south. Cyclonic depressions cross Drake Passage from the northwest towards the southeast (U.S. Navy, 1965; American Geographical Society, 1967) and their frontal activity is mainly responsible for the precipitation, although there is a significant orographic influence. This is illustrated by the annual precipitation sums for both sides of the Andean summits. For instance, the western islands facing the Pacific Ocean annually receive several thousand millimetres of precipitation, while locations on the lee side receive only a few hundred millimetres (Liljequist, 1970). Thus, the maritime climate over the western islands is replaced by a steppe climate northeast of the summits. The precipitation distribution over the year is fairly even with small relative variations and no pronounced dry season (Liljequist, 1970).

Climate stations in southernmost South America are scanty and only a few have long records. Among these are Faro Evangelistas $\left(52.5^{\circ} \mathrm{S}, 75.1^{\circ} \mathrm{W}\right)$, Bahia Felix $\left(52.9^{\circ} \mathrm{S}, 74.6^{\circ} \mathrm{W}\right)$, Punta Arenas $\left(53.0^{\circ} \mathrm{S}, 71.0^{\circ} \mathrm{W}\right)$ and Ushuaia $\left(54.7^{\circ} \mathrm{S}, 68.2^{\circ} \mathrm{W}\right.$ ) (Fig. 1). The climate station Faro Evangelistas is located at a lighthouse on a small rocky island at the western entrance of the Straits of Magellan. Bahia Felix is also at the strait entrance but in a small bay open to the northeast on the lee side of summits $700 \mathrm{~m}$ high running from northwest to southeast. The climate station at Punta Arenas is located at the airport situated about $15 \mathrm{~km}$ north of the city, in an open area close to the shore of the Straits of Magellan. The station at Ushuaia is located at the airport, close to the Beagle Channel. North of the city, there are summits over $1000 \mathrm{~m}$ high. (The climate data in this paper have been collected by the Chilean National Weather Service (Dirección Meteorológica de Chile).)

\section{GLACIERS AND GLIMATE}

The driving forces in glaciers are the mass balance and the force of gravity. The degree of change in net mass balance as a function of the altitude may be described as the net-balance gradient. In continental areas, we may expect gradients lower than $0.5 \mathrm{~m}$ per $100 \mathrm{~m}$; in maritime areas the gradient exceeds $1.5 \mathrm{~m}$ per $100 \mathrm{~m}$. The melting is controlled primarily by the adiabatic lapse rate. The rate of sublimation is governed by the air humidity and the rate of incoming solar radiation. Excluding calving as an ablation process, melting and sublimation are the important ablation parameters.

Though the dry adiabatic lapse rate is higher than the corresponding wet adiabatic lapse rate, the sublimation and transport of sensible heat by katabatic winds in dry areas give only little change in ablation as a function of the altitude. In maritime areas, ablation is primarily governed by melting.

The accumulation pattern and the length of the accumulation season differ significantly between maritime and continental areas. In maritime areas, snowfall is relatively evenly distributed but it varies as a function of the altitude. The lengths of the accumulation and ablation periods are significantly different at the top and at the front of a glacier. In an extreme case, a maritime glacier may have net accumulation all the year round at the head of the glacier, whereas at the same time there is year-round melting at the front. In a continental environment, snowdrift is important, giving an uneven snow distribution, which is to a high degree governed by the local topography. In comparison with maritime areas, the seasonal changes are sharp and there is little delay between the initiation of the melt season at the front and at the top of a glacier.

\section{GLIMATIC DEVELOPMENT DURING THE LAST CENTURY}

Large-scale weather patterns in Chile are governed by the position of the subtropical southwestern Pacific anticylone and the occurrence of El Niño (Aceituno, 1988). Airpressure records that may indicate the position of the subtropical anticyclone are too short to tell whether there has been any change in the frequency of south-going events and El Niño is not taken into account in this context, as it influences climate on an annual time-scale.

However, the local climate may be described as follows:

The precipitation in the southernmost region has a cyclonic frontal origin associated with depressions moving from the northwest towards the southeast, with centres crossing Drake Passage towards the Weddell Sea where they fill. While approaching southern Chile, they are normally at a rather advanced stage in their evolution and correspond to occluded systems. Assuming a cold type of occlusion, precipitation must occur with southwest and west winds, favouring accumulation of snow on slopes facing in these directions and föhn-type conditions on the lee-side of the summits.

However, the cyclonic fronts are most active further north where the climatological precipitation maxima, as well as the large Patagonian ice fields, are located. Thus, in Faro Evangelistas and in Bahia Felix, rainfall maxima occur in March (Fig. 2), when weather systems are becoming more active and are still close to their southernmost latitude. Minima, however, occur in the early winter, a fact probably due to the northward drift of the weather systems but also to the deficient recording of snow.

Annual sums of precipitation at Bahia Felix and Punta Arenas, when properly smoothed, exhibit a downward 

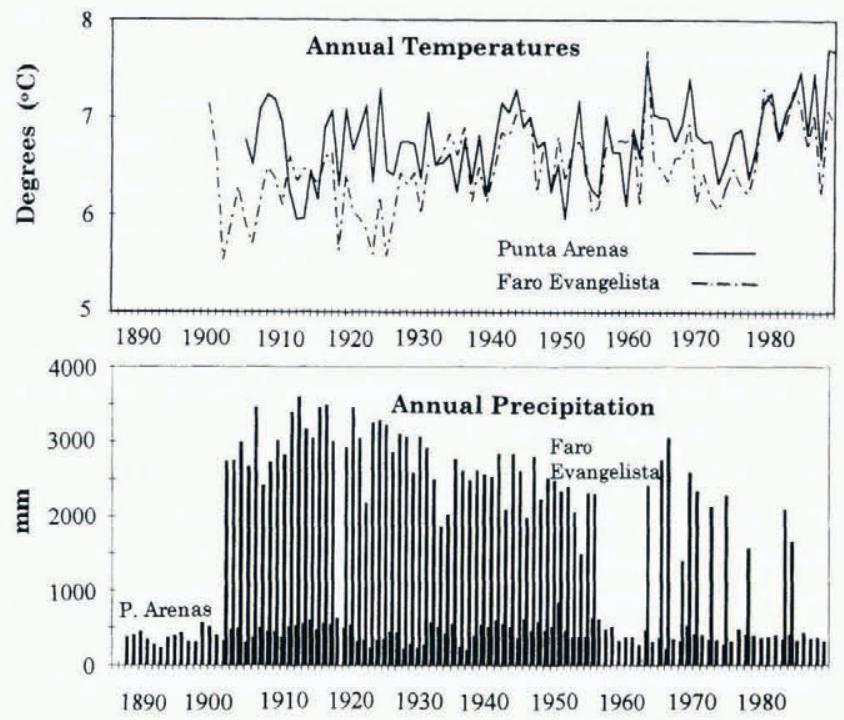

Year

Fig. 2. Annual temperatures and precipitation at Faro Evangelista and Punta Arenas. Both stations show a positive trend in the annual temperature. The negative trend in the precipitation in the record from Faro Evangelista is striking, though there are many gaps in the record. The trend is not clear for the entire Punta Arenas record but it is significantly negative from 1950 until the present. (Data from Dirección Meteorológica de Chile.)

trend after 1920 (Fig. 2). This trend is less clear in the winter sums but rainy winters have become unusual since the 1950s. At Ushuaia, there is no trend at all in the winter precipitation figures. Therefore, it seems that, although annual sums show a decrease during this century, there is no significant trend in the winter precipitation in southernmost South America.

Monthly mean temperatures of the southern part of South America have increased by about $0.5^{\circ}$ since the 1930s (Rosenbluth and Fuenzalida, 1991). Over this time period, daily minimum temperatures have increased, while maximum temperatures remain almost invariable. Such warming becomes better defined from latitudes $48^{\circ}$ to $63^{\circ} \mathrm{S}$ and might be responsible for the general glacier retreat over the Patagonian ice fields. Because of the topographic obstacle formed by the Andes, large local deviations would be expected between nearby sites (Peña and Gutiérrez, 1992).

There is one important discrepancy during the 1960s between the data record used in this paper and some former published versions (Warren and Sugden, 1993). In the latter record, there is a cold period during the 1960s. This cold period is not shown in the original series of nearby climatic stations; it is present only in the Punta Arenas record, which during this period was collected at a site located $25 \mathrm{~m}$ higher than before and after the 1960s. The climate record of Punta Arenas has been the object of a special analysis in order to adjust for changes in the environment, and changes in instrument elevation and change in the observation site. According to this analysis, the record is most reliable from 1905 to the present, Therefore, we feel that our correction is in order for this period.

\section{CHANGES IN THE EXTENT OF GLAGIERS 1943-93}

According to Aniya (1992), the outlet glaciers of the northern Patagonian ice field show an increased recession rate during the last decade, especially the glaciers facing west. Glaciers oriented towards the east show less dramatic changes, though they are generally retreating. In the southern Patagonian ice field the situation is the opposite, with increased recession rates on the eastern side and only a little change on the western side Warren and Sugden, 1993). However, there are some anomalous reactions, such as that of Moreno Glacier, orientated towards the east. It has been stable during most of this century, a peculiarity which has been suggested by Aniya and Skvarca (1992) to have been caused by the steep surface topography of the glacier at its equilibrium-line altitude (ELA).

For this study, a number of glaciers were selected on different sides of the mountain range, with different orientations and of different sizes. Accessibility and the quantity of information available from aerial photographs also influenced the selection. This sampling was based on aerial photographs taken in 1943 and 1984. The rate of recession was measured in the aerial photographs, which were scaled using the Instituto Geográfico Militar de Chile (1984a, b) maps. Prior to the first field season, 20 glaciers were selected, of which 16 were studied in the field during the seasons 1993 and 1994. The glaciers examined in the field are shown in Table 1.

In general, the extents of the glacier fronts in Darwin Cordillera have changed as follows: prior to 1943 there was a slight retreat of glaciers along the northern side of the Cordillera, especially in the northwest where the climate conditions are rather continental. In the south there are also indications of a slight retreat of the glaciers. The extreme reaction of Ventisquero Marinelli (Figs 1 and 3 ; Table 1) is only partly a response to climatic changes. The warm 20 th century may have caused a significant thinning of the tongue but the main reason for the dramatic recession is the local topography. The glacier is situated in a fjord and, from the turn of the century until at least 1943, the glacier reached a frontal moraine where the ice was grounded. The trim line along the valley sides shows a significant slope, which may indicate that the entire glacier tongue was grounded during its maximum. While thinning, the basal shear stress decreased owing to a decreased basal friction and the velocity of the ice could remain high, providing a large mass flux towards the extensive front. The relatively high velocities could drain mass efficiently from the upper part of the glacier, such as ice streams can drain the mass from ice sheets (Hughes, 1992). Until at least the mid 1960 s, the glacier-front position remained stable close to the old frontal moraine (Fig. 3). The frontal moraine may have acted like a dam, preventing a too extensive rate of calving. Finally, when the glacier front became rather thin, it broke up very quickly. This seems to be a plausible explanation as to why the glacier did not retreat during the first half of this century but then retreated extremely fast during the second half of the century.

A few kilometres east of Ventisquero Marinelli there is a glacier referred to as No. 4 in Figure 1 and Table 1 
Table 1. Results of glacier mapping in Darwin Cordillera. Glaciers numbers refer to Figure 1. The maximum extent is determined by trim lines and moraines visible in aerial photographs taken in 1943. However, the date of this maximum is not possible to state but, as these fronts are surrounded by fast-growing Nothofagus trees, the observed trim lines are not likely to be older than 50-100 years. The physical data on the glaciers are determined from aerial photographs taken in 1984 and have been scaled by the use of Carta Preliminar (Instituto Geográfico Militar de Chile, 1984a, b)

\begin{tabular}{|c|c|c|c|c|c|c|c|}
\hline \multirow[t]{2}{*}{ Glacier } & \multirow[b]{2}{*}{ Number } & \multicolumn{2}{|c|}{ Area orientation } & \multicolumn{4}{|c|}{ Change in length } \\
\hline & & $\mathrm{km}^{2}$ & $A c c$. & $A b l$. & $\operatorname{Max}-43$ & $43-60$ & $60-93$ \\
\hline \multirow[t]{2}{*}{ Bahia Broken } & 1 & 52 & NW & $\mathrm{N}$ & - & -0.5 & -0.2 \\
\hline & 2 & 69 & NW & $\mathrm{N}$ & - & +1.5 & 0.0 \\
\hline \multirow[t]{2}{*}{ Ventisquero Marinelli } & 3 & 142 & $\mathrm{~N}$ & $\mathrm{~N}$ & 0.0 & -0.2 & -5.0 \\
\hline & 4 & 17 & $\mathrm{~N}$ & $\mathrm{~N}$ & -1.4 & -0.4 & -0.8 \\
\hline \multicolumn{8}{|l|}{ Cordon Central } \\
\hline Ventisquero & 5 & 3 & $\mathrm{~S}$ & $\mathrm{~S}$ & -0.7 & -0.3 & -0.7 \\
\hline \multirow[t]{2}{*}{ Stoppani } & 6 & 75 & $\mathrm{E}$ & $\mathrm{SE}$ & -0.5 & -0.2 & -0.3 \\
\hline & 7 & 26 & NE & $\mathrm{NE}$ & -0.1 & -0.1 & -0.1 \\
\hline Pico Frances & 8 & 16 & $\mathrm{E}$ & $\mathrm{E}$ & 0.0 & $-0.6^{*}$ & \\
\hline V. Holandia & 9 & 15 & $\mathrm{~S}$ & $\mathrm{~S}$ & 0.0 & -0.3 & -0.5 \\
\hline V. Romanche & 10 & 24 & $\mathrm{~S}$ & $\mathrm{~S}$ & & & \\
\hline \multirow[t]{6}{*}{ Bahia Pia } & 11 & 11 & SW & NW & - & 0.0 & +0.2 \\
\hline & 12 & 23 & SW & SW & - & 0.0 & +0.4 \\
\hline & 13 & 13 & SW & W & - & -0.4 & 0.0 \\
\hline & 14 & 24 & SW & $\mathrm{S}$ & - & 0.0 & +0.4 \\
\hline & 15 & 7 & $\mathrm{SE}$ & SW & -0.1 & 0.0 & 0.0 \\
\hline & 16 & 28 & $\mathrm{~S}$ & $\mathrm{SE}$ & -0.2 & -0.3 & 0.0 \\
\hline
\end{tabular}

* Glacier No. 8 has retreated $600 \mathrm{~m}$ between 1943 and 1993.

(Fig. 3). In contrast to its neighbour, this glacier has been steadily receding since 1943. However, between 1984 and 1994, some nunataks have appeared 3-4 km from the front. Their sizes have grown dramatically as a consequence of thinning of the glacier surface and the present ice flux passing them is very little. Thus, it is likely that the recession rate will increase during the coming years and the tongue will probably melt as dead ice.

For the glaciers located nearby in Bahia Broken, the conditions are somewhat different. Glacier No. 2 (Fig. 1; Table 1) advanced between 1960 and 1993. The climatic reason why this glacier has not been retreating, as other north-oriented glaciers have been, may be the fact that its accumulation area is oriented towards the west. A nearby glacier, glacier No. 1, has experienced a slight recession during the same period. The different behaviour of these two glaciers can most probably be explained by differences in the topography at their fronts. The topographic conditions have been unchanged at glacier No. 1 but the fjord where glacier No. 2 ends has been infilled by sediments from the glacier. In 1993, there was a delta and some moraines in front of the present tongue which are not visible on previous aerial photographs. As the shoreline progresses down-fjord by sedimentation, the glacier front advances as a consequence of the reduced calving rate, such as described by Alley (1991).

In the Cordon Central area, there are a number of small alpine glaciers. All of them have become significantly smaller during this century. The largest one is at present $3 \mathrm{~km}^{2}$ (Fig. 4). A clear trim line indicates an areal extent at the turn of the century that was about twice as great as the present one. The recession rate seems to have been more or less constant, at $10-15 \mathrm{~m}_{\text {year }}{ }^{-1}$ during this century. There is no indication of a declining recession rate.

Ventisquero Stoppani (No. 6 in Fig. 1 and Table 1) is situated on the northeast slope of Pico Frances $(2150 \mathrm{~m}$ ) and Pico Italia $(2360 \mathrm{~m})$. It is a large glacier with a divided accumulation area. Its earlier larger extent is manifested by large frontal moraines. A slight recession has been observed for the last 50 years.

Just south of Ventisquero Stoppani, there is a glacier called 7 in Table 1 and Figure 1. It is heavily loaded with sediments at its front, which is in a tributary valley to the one where Ventisquero Stoppani ends. Although the front of glacier 7 shows no sign of recession, the rate of thinning is substantial.

East of Pico Frances, there is a glacier which shows a more or less constant rate of recession (No. 8 in Fig. 1 and Table 1). The total recession over the 50 year period is $600 \mathrm{~m}$. 


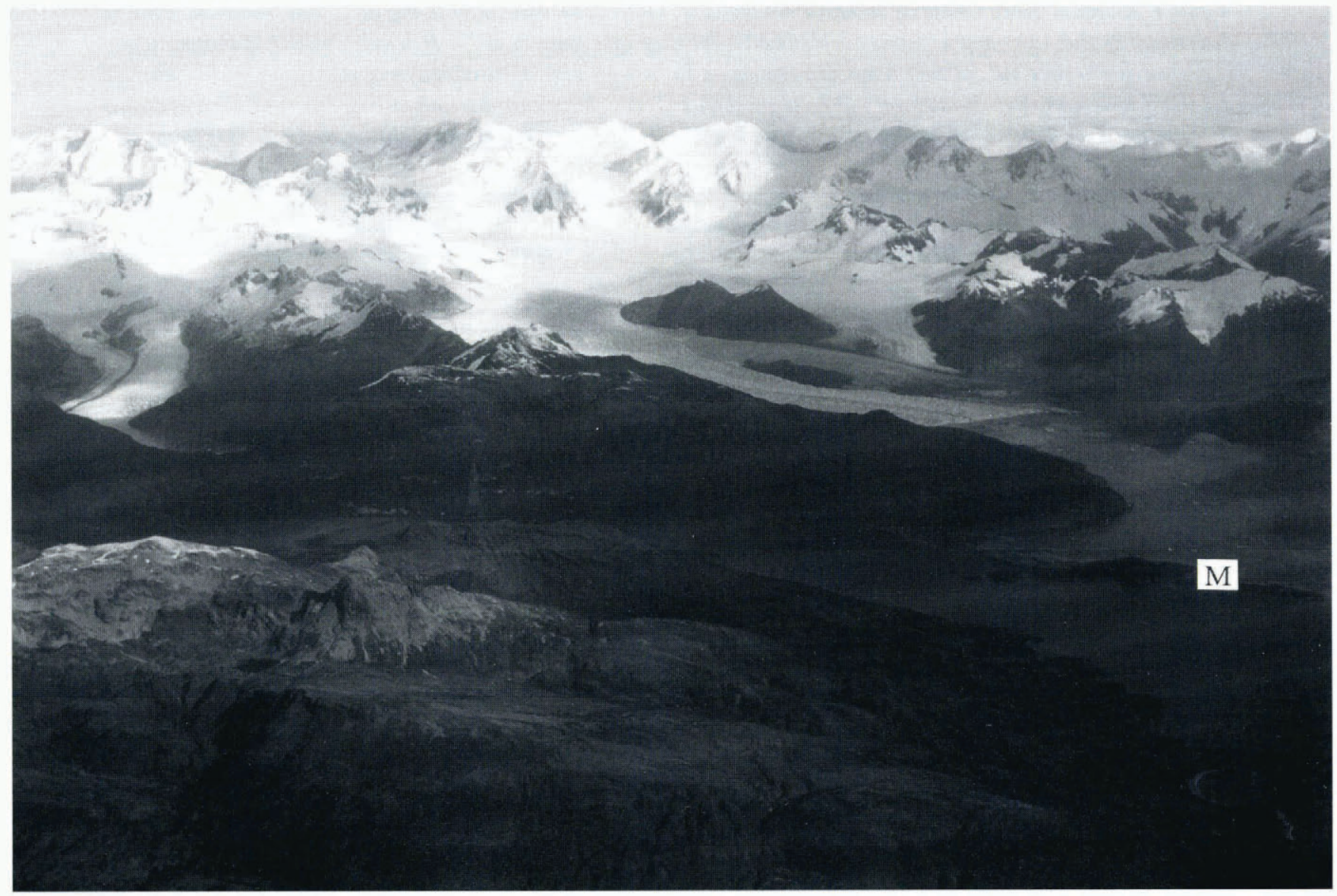

Fig. 3. Ventisquero Marinelli (right) on the northern side of Mount Darwin. Until the 1970s, the glacier reached its outermost frontal moraine (M). The rapid retreat during the 1980s is mainly a topographic effect, as the glacier has retreated over a deep fjord. However, the spectacular $5 \mathrm{~km}$ recession of Ventisquero Marinelli contrasts with the advancing glaciers on the southern side of Mount Darwin. (Pholograph taken from the north on 18 April 1994 by P. Holmlund.)

Ventisquero Holandia (No. 9 in Fig. 1 and Table 1) calves into a lake which is dammed by the former frontal moraine of the glacier. The lake has formed since 1943 and its present size is approximately $500 \mathrm{~m} \times 500 \mathrm{~m}$. As long as the glacier is calving into the lake, climatic interpretation is difficult. The rate of recession has gradually increased since 1943. Whether this is climatically induced or is caused by topography is not yet known.

Ventisquero Romanche (No. 10 in Fig. 1 and Table 1) terminates in an icefall into Beagle Channel. It is oriented towards the south and its present size is close to its Holocene maximum, though there has been a slight recession during the last decade. However, from 1943 to 1984, the front seems to have been more or less stable, with only minor fluctuations occurring.

The Bahia Pia area is characterized by a deep fjord with calving glaciers. Glaciers 11 and 12 show no sign of change in extent during this period. However, in 1943, glacier 12 partially covered the peninsula at the northern side of the tongue with a branch-like remnant of a former, slightly larger extension. The northern side of the peninsula was covered by a forest at that time and the southern side showed exposed bedrock with no sign of vegetation. Along the southern shore, there was still a significant cover of crevassed glacier ice.

In 1994, the boundary between the old forest and the area newly exposed in 1943 was still visible but the whole peninsula is now covered by a forest. Thirty tree rings could be counted in a core taken from one of the largest Nothofagus betuloides found, situated at a site that was icecovered in 1943, indicating a rapid colonization in the area. The front of glacier 12 is grounded on bedrock but it is actively calving into the fjord. Whether this calving indicates a reactivation of the front or not is not possible to conclude from the data available.

Glaciers 13 and 14 show a slightly different situation (Fig. 5). Glacier 13 retreated a few hundred metres between 1943 and 1984 and has shown no change over the last decade. Glacier 14, on the other hand, gives evidence of a significant advance; tree cores only $20 \mathrm{~m}$ from the snout (Nothofagus betuloides) give ages of at least 92 and 93 years, respectively, indicating that the glacier is now at its 20th century maximum. The tree rings also indicate a significant drop in tree-ring width 20-30 years ago, which may indicate an advance of the glacier to the present position.

Trim lines along the sides of glaciers 15 and 16 indicate that there was a slight retreat prior to 1943 and there has been no significant change in extent or thickness of these two glaciers since that year.

\section{DISGUSSION}

On the northern side of Darwin Cordillera, glaciers seem to have retreated continuously during the 20 th century. 


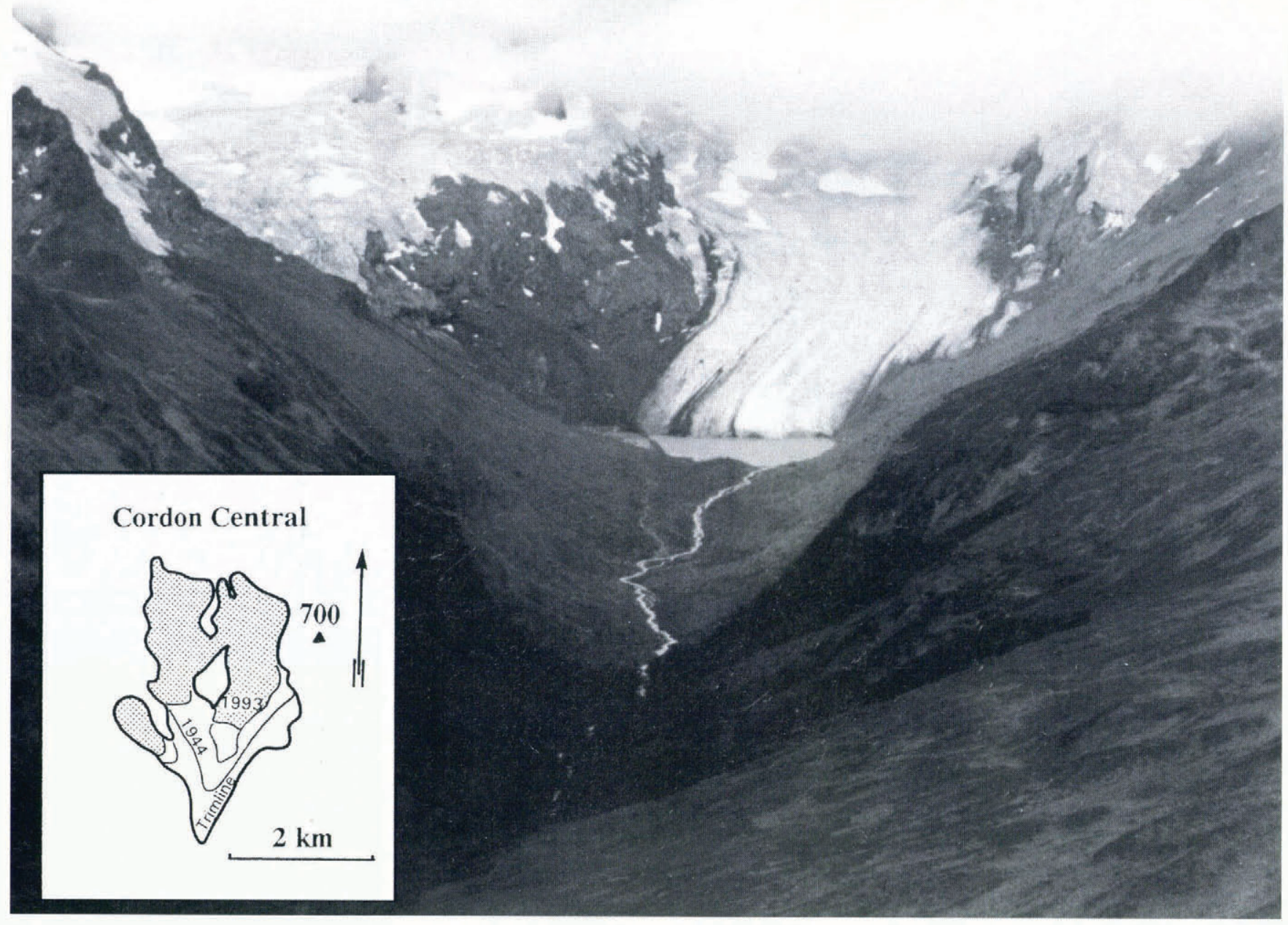

Fig. 4. The largest glacier (glacier No. 5) in the Cordon Central massif. This glacier has had an almost constant recession rate during the last 50 years. At about the turn of the century, the extent of the glacier was similar to the trim line. In 1985, the two tongues were still joined as one tongue and a proglacial lake formed. (Photograph taken from the soulh on 11 February 1993 by P. Holmlund.)

Lliboutry (1956) stated that there were only minor changes in glacier-front positions prior to 1943, meaning that in general there was little change, although some glaciers had experienced a recession. Ventisquero Marinelli is a major exception to any kind of general pattern. Its dramatically increased recession rate is only partially due to climatic changes; it is in part a topographical phenomenon.

The glaciers along the southern side are either in a stable state or an advancing state. Aerial photographs since the 1940 s show a remarkably stable situation. It is interesting to note that the most extreme reactions in this area can be observed on either side of the highest mountain in the area, Mount Darwin (2469 ma.s.l.). The glaciers facing south are advancing and the glaciers facing north are rapidly receding (Figs 1, 3 and 5). Several of these glaciers end at shores or in fjords, which makes several authors disqualify them as climate indicators (Trabant and others, 1991; Warren, 1993). However, calving and non-calving glaciers in this area are reacting consistently, in a geographical pattern. Therefore, in this compilation there is no reason to treat calving glaciers differently from glaciers ending on land.
During the last 50 years, the climate in the area has shown a significant increase in temperature but no change or a decrease in precipitation. Such a climatic scenario is expected to cause recession on both maritime and continental glaciers, with a stronger reaction on the latter. This scenario is well in accord with what is observed on the northern and western parts of the Cordillera but it is not in agreement with the observations from the southern rim. Even if these glaciers are situated in a maritime environment and are thus fed by high amounts of precipitation, the observed climatic change should show a tendency for recession, as a consequence of an increased ablation rate. However, the two data sets would fit each other if there were indications of increased wind activity in the area. This would cause orographic precipitation on the windward side and dry föhn winds on the leeward side of the Cordillera. However, there are no signs of increased cyclonic activity, as it would be detected as a change in the rate of precipitation at the climate stations. In addition, the wind information from the climatic stations is sparse and is influenced too much by the local topography to be reliable. 


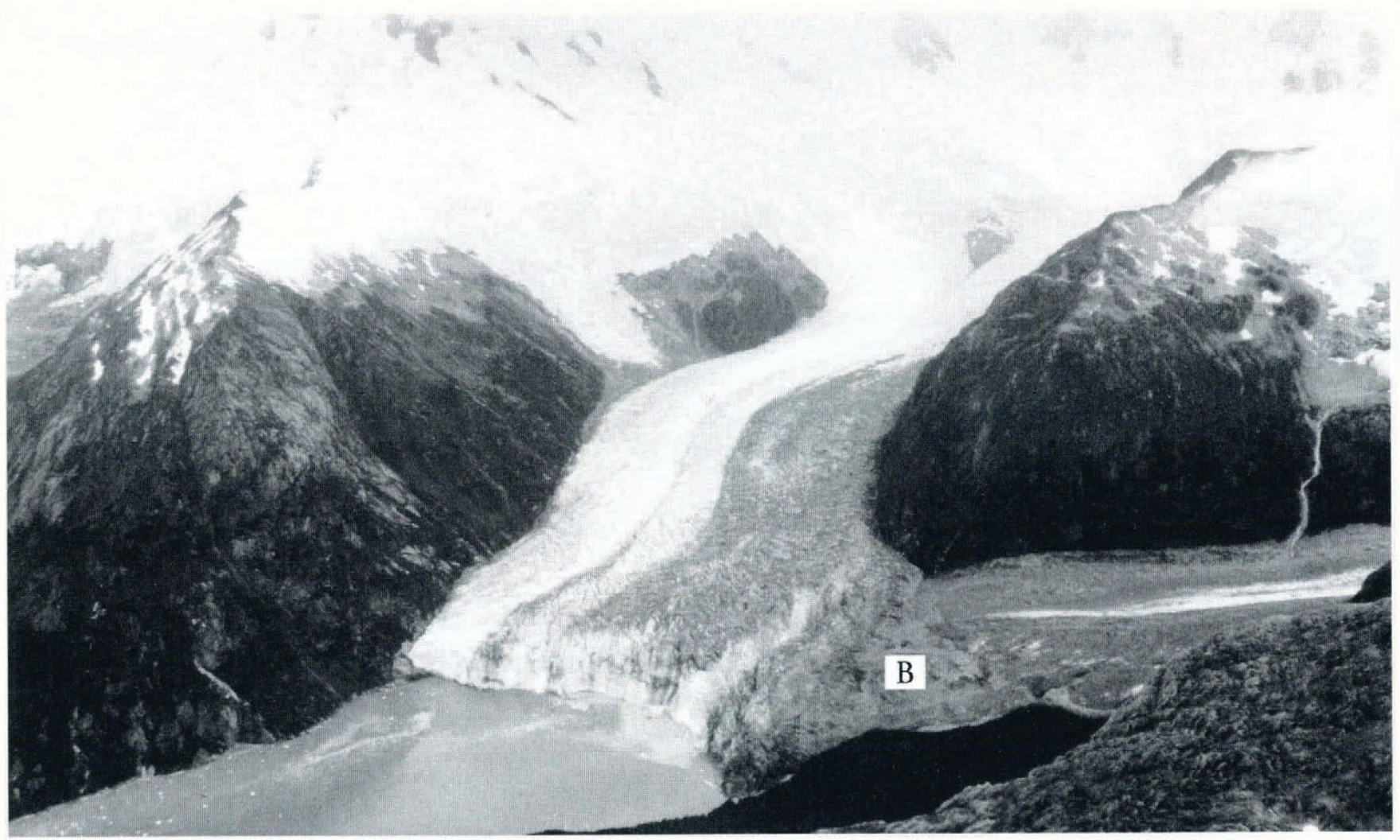

Fig. 5. Glaciers originating from the slope of Mount Darwin ending in the fjord Bahia Pia (glaciers Nos 13 (left) and 14 (right) in Figure 1 and Table 1) on the southern side of Darwin Cordillera. Dendro samples laken only $20 \mathrm{~m}$ from the present front indicale that the glacier is now at its maximum extent for this century. (B) on glacier 13 indicates a bedrock obstacle, separating the two glacier fronts. (Photograph laken 11 February 1993 by P. Holmlund.)

Although reliable climate data are absent, there is indirect information supporting the idea that the wind activity has changed. During occasions when the subtropical anticyclone extends far south, it blocks the west winds from approaching the west coast where the Patagonian ice fields are situated. At the same time, the cyclones are forced southward into Drake Strait, which would also give less precipitation in the south. But, at the same time, the temperature gradient is strengthened between the Hadley cell and the polar cell, which may cause higher wind activities and speeds. A tendency for a southward migration of the subtropical convergence zone, in addition to the general warming of this century, could explain the odd response of the maritime glaciers of southernmost Chile.

In northern Scandinavia, we have experienced a temperature increase in the beginning of this century (Alexandersson and Eriksson, 1989) and a slight increase in precipitation in the mountain area during the last decade (Holmlund, in press). In Scandinavia, most glacier fronts now have reached a close to steady-state position or at least a declining recession rate Holmlund, 1993). The last years' surplus of mass has not yet led to advances of glacier fronts. The pattern of reaction is therefore somewhat different in Darwin Cordillera and in the Scandinavian mountains.

\section{CONGLUSION}

There is a clear difference in behaviour of the glaciers on either side of Darwin Cordillera which is suggested here to be explained by an increased orographic effect. The southern slopes would receive high rates of precipitation with occluded fronts. This increase in precipitation would balance the increased melting rate as a consequence of warmer summers. On the northern side, the situation would be different, with no increase in precipitation but higher temperatures and drier air giving an increased ablation rate; ablation by both melting and sublimation.

This study shows that caution should be used when interpreting glacier reactions in areas with sparse climatic information. Glaciers may be highly influenced by local conditions, such as is the case at Ventisquero Marinelli. However, while using a large number of glaciers, including anomalously reacting ones, new climatic information which may not be clearly seen in climatic records can be attained.

\section{ACKNOWLEDGEMENTS}

This project was funded by the Swedish Agency for Research Cooperation with Developing Countries (SAREC). The programme was greatly supported by the CONICYT of Chile. Thanks are due to Dr G. Rosquist, M. Eriksson, J. Kuylenstierna and R. Kjessel for taking part in the field parties of 1993 and 1994. Thanks are also due to C. Porter for taking care of the logistics on his boat during the 1994 field campaign. Professor W. Karlén and A. Schytt contributed with critical and inspiring comments on the text. 
The language was improved by Mrs J. Karlén and the figures were drawn by Mrs K. Weilow.

\section{REFERENCES}

Aceituno, P. 1988. On the functioning of the southern oscillation in the South American sector: Part I. Surface climate. Mon. Weather Rer., 116, $505-524$.

Alexandersson, H. and B. Eriksson. 1989. Climate fluctuations in Sweden 1860-1987. Sueriges Meteorologiska och Hydrologiska Institut. Rapporter. Meteorologi och Klimatologi 58.

Alley, R. B. 1991. Sedimentary processes may cause fluctuations of tidewater glaciers. Ann. Glaciol., 15, 119-124.

American Geographical Society. 1967. The Antarctic atmosphere: climatology of the surface environment. Antarct. Map Folio Ser. 8.

Aniya, M. 1992. Glacier variation in the Northern Patagonia Icefield, Chile, between 1985/86 and 1990/91. Bull. Glacier Res. 10, 8390.

Aniya, M. and P. Skvarca. 1992. Characteristics and variations of Upsala and Moreno glaciers, southern Patagonia. Bull. Glacier Res. $10,39-53$.

Bradley, R.S. and P.D. Jones, 1993. "Little Ice Age" summer temperature variations: their nature and relevance to recent global warming trends. Holocene, 3 4), 367-376.

Dalziel, I. W. D. and R. Cortés. 1972. Tectonic style of the southernmost Andes and the Antarctandes. In Proceedings. 24th International Geographical Congress, Montreal, Canada. Section 3, 316-327.

Holmlund, P. 1993. Surveys of post-Little Ice Age glacier fluctuations in northern Sweden. 2. Gletscherkd. Glazialgeol., 29 1), 1-13.

Holmlund, P. In press. Mass balance studies in northern Sweden. Z. Gletscherkd. Glazialgeol.
Hughes, T. 1992. On the pulling power of ice streams. F. Glaciol., 38 (128), 125-151.

Instituto Geográfico Militar de Chile. 1984a. Canal Beagle. Sheet 5468. Scale 1:250000. Third edition. Santiago de Chile, Instituto Geográfico Militar de Chile.

Instituto Geográfico Militar de Chile. 1984b. Cordillera Darwin. Sheel 5470. Scale 1:250000. Third edition. Santiago de Chile, Instituto Geográfico Militar de Chile.

Liljequist, G. 1970. Klimatologi. Stockholm, Generalstabens Litografiska Anstalt.

Ljungner, E. 1949. East-west balance of Quaternary ice caps in Patagonia and Scandinavia. Bull. Geol. Inst. Univ. Upps., 33.

Lliboutry, L. 1956. Nieves y glaciares de Chile: fundamentos de glaciologia. Santiago de Chile, Ediciones de la Universidad de Chile.

Peña, H, and R. Gutiérrez. 1992. Statistical analysis of precipitation and air temperature in the Southern Patagonia Icefield. In Naruse, R. and M. Aniya, eds. Glaciological researches in Patagonia, 1990. Tokyo, Japanese Society of Snow and Ice, 95-107.

Rosenbluth, B. and H. Fuenzalida. 1991. Recent temperature variations in austral South America. In Proceedings. 2nd International Congress of the Brazilian Geophysical Society, Salvador-Bahia, October 27-November 1, 1991, 1006-1011.

Trabant, D. C., R.M. Krimmel and A. Post. 1991. A preliminary forecast of the advance of Hubbard Glacier and its influence on Russell Fiord, Alaska. U.S. Geol. Surv. Water-Resources Investigation Report 90-4172.

U.S. Navy. 1965. Marine climatic allas of the world. Vol. WII. Antarctic. Washington, DC, Chief of Naval Operations. (NAVWEPS 50-1 C-50.

Warren, C. R. 1993. Rapid recent fluctuations of the calving San Rafael glacier, Chilean Patagonia: climatic or non-climatic? Geogr. Ann., $75 \mathbf{A}(3), 111-125$.

Warren, C. R. and D. E. Sugden. 1993. The Patagonian ice fields: a glaciological review. Arct. Alp. Res., 25 4), 316-331.

MS received 18 July 1994 and accepled in revised form 24 January 1995 